\title{
Development of enzyme-linked immunosorbent assay (ELISA) for T-2 toxin using monoclonal antibodies
}

\author{
K. Ohtani*1, O. KaWAmura*1, H. KajII*1, J. Chiba*2, and Y. Ueno*1 \\ 大谷 勝己*1, 川村 理*1, 梶井 浩志*1, 千葉 丈*2, 上野 芳夫*1: \\ モノクローナル抗体を用いた T-2 トキシンの酵素免疫測定法の開発
}

\begin{abstract}
Summary
Two monoclonal antibodies $(7 \mathrm{D} 4,6 \mathrm{E} 9)$ reactive with $\mathrm{T}-2$ toxin (T-2) were prepared. The antibody $7 \mathrm{D} 4$ was also reactive with T-2 hemisuccinate (T-2 HS) and acetyl T-2 toxin, but less reactive with $\mathrm{HT}-2,3^{\prime}-\mathrm{OH}-\mathrm{T}-2$, and $3^{\prime}-\mathrm{OH}-\mathrm{HT}-2$ toxins. By using the antibody $7 \mathrm{D} 4$ in the indirect competitive ELISA method, the least detectable limit for T-2 was about $25 \mathrm{pg}$ per assay.
\end{abstract}

$\mathrm{T}-2$ toxin (T-2) is one of the well known toxic metabolites of Fusarium, and exhibits a potent inhibition of protein synthesis in mammalian cells ${ }^{1,2)}$. At present, a contamination of this toxin in foods and feeds is a serious problem in health. We prepared monoclonal antibodies (mAbs) for $\mathrm{T}-2$, useful for ELISA, to develop a more specific and sensitive assay method.

\section{Materials and Methods}

The method proposed by $\mathrm{Chu}$ et al. ${ }^{3)}$ was modified for the preparation of T-2 HS-bovine serum albumin ( $\mathrm{T}-2$ HS-BSA), T-2 HS-ovalbumin (T-2 HS-OVA), and T-2 HS-kyhole limpet hemocyanin (T-2 HS-KLH).

Spleen cells of BALB/c mouse immunized with

*1 Faculty of Pharmaceutical Science, Science University of Tokyo (12 Funagawaramachi, Ichigaya, Shinjuku-ku, Tokyo 162) 東京理科大学・薬学部 (テ162 新宿区市ヶ谷船 河原町12)

*2 Department of Pathology, National Institute of Health (2-10-35, Kamiosaki, Shinagawaku, Tokyo 141)

国立予防衛生研究所・病理部（テ141 品川区上 大崎2-10-35)
T-2 HS-BSA were fused with SP $2 / 0$ myeloma cells using $50 \%$ polyethylene glycol 4000 . Hybridoma cells secreting antibodies against $\mathrm{T}-2$, which were cloned by repeating the limiting dilution method, were injected intraperitoneally into the mice. Then $\mathrm{mAb}$ produced were purified from the ascites.

The activity of $\mathrm{mAb}$ against $\mathrm{T}-2$ was detected with ELISA by using T-2 HS-OVA and T-2 HS$\mathrm{KLH}$ as antigen. The cross reactivity of $\mathrm{mAb}$ for T-2 analogs was analyzed by the indirect competitive ELISA method.

\section{Results and Discussion}

We prepared two stable hybridoma clones (7 D 4, $6 \mathrm{E} 9$ ) producing $\mathrm{mAb}$ for $\mathrm{T}-2$. As shown in Figs. 1 and 2, the mAbs $7 \mathrm{D} 4$ and $6 \mathrm{E} 9$ exhibited a potent reactivity to $\mathrm{T}-2, \mathrm{~T}-2 \mathrm{HS}$ and acetyl $\mathrm{T}-2$, and the mAb $7 \mathrm{D} 4$ showed a weak reactivity to T-2 metabolites such as HT-2 and $3^{\prime}-\mathrm{OH}-\mathrm{T}-2$ toxins. The least detectable limits of $\mathrm{T}-2$ with mAbs $7 \mathrm{D} 4$ and $6 \mathrm{E} 9$ in the indirect competitive ELISA method were $25 \mathrm{pg}$ and $25 \mathrm{ng}$ per assay, respectively. The sensitivity of the present $\mathrm{mAb}$ $7 \mathrm{D} 4$ is much higher than the mAb reported 
$7 D 4$

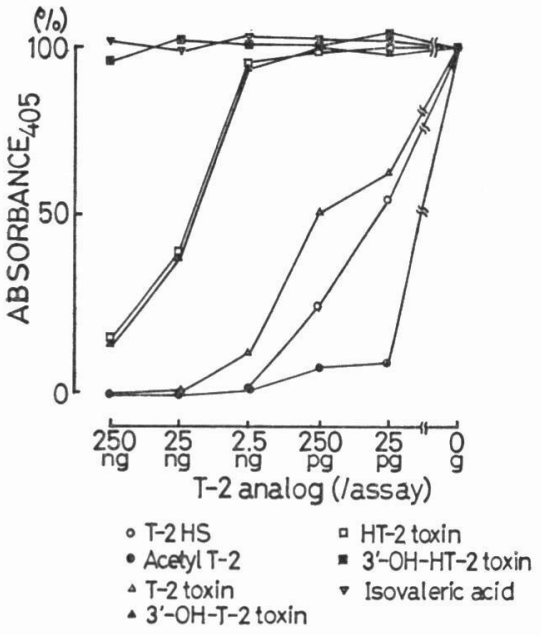

Fig. 1. The specificity of the mAb $7 \mathrm{D} 4$ in the indirect competitive ELISA for T-2 analogs

6E9

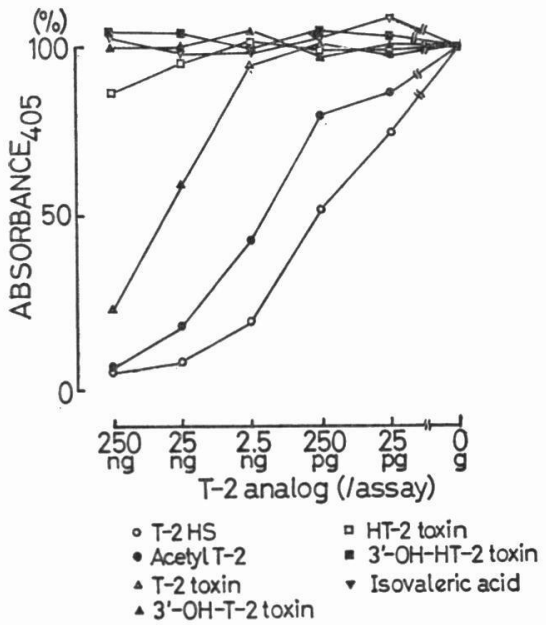

Fig. 2. The specificity of the $\mathrm{mAb} 6 \mathrm{E} 9$ in the indirect competitive ELISA for T-2 analogs

elsewhere ${ }^{4)}$.

As shown in Table 1, the cross reactivities of the mAb $6 \mathrm{E} 9$ to $\mathrm{T}-2 \mathrm{HS}$ and acetyl T-2 were
Table 1. Cross reactivity of monoclonal antibodies

\begin{tabular}{|c|c|c|}
\hline \multirow{2}{*}{ T-2 analogs } & \multicolumn{2}{|c|}{ monoclonal antibodies } \\
\hline & 7D4 & $6 \mathrm{E} 9$ \\
\hline $\mathrm{T}-2 \mathrm{HS}$ & $0.035^{*}(7.5)^{* *}$ & $0.031(465)$ \\
\hline Acetyl T-2 & $<0.025(>10)$ & $0.532(272)$ \\
\hline T-2 toxin & $0.260(1.0)$ & $144 \quad(1.0)$ \\
\hline $3^{\prime}-\mathrm{OH}-\mathrm{T}-2$ toxin & $16.5(0.016)$ & $>250(<0.58)$ \\
\hline HT-2 to & $19.7 \quad(0.015)$ & $>250(<0.58)$ \\
\hline-2 toxin & $>250(<0.0001)$ & $>250(<0.58)$ \\
\hline sovaleric acid & $>250(<0.0001)$ & $>250(<0.58)$ \\
\hline $\begin{array}{l}* \text { Amount (ng } \\
\text { placement. }\end{array}$ & per assay yie & ling $50 \%$ dis- \\
\hline $\begin{array}{l}\text { ** Numbers in } \\
\text { ratio to T-2 }\end{array}$ & $n$ parentheses ind & dicate relative \\
\hline
\end{tabular}

465 and 272 times higher than T-2, whereas those of the $\mathrm{mAb} 7 \mathrm{D} 4$ were 7.5 and 10 times, respectively. These results indicate that the mAb $7 \mathrm{D} 4$ shows high sensitivity and specificity for T-2.

ELISA method with the present mAb 7D 4 may be simple, rapid, sensitive, and excellent for the detection and quantitation of T-2 in foods, feeds, and biological fluids.

\section{Acknowledgement}

We are grateful to Dr. T. Yoshizawa (Kagawa University, Japan) for a kind gift of $3^{\prime}-\mathrm{OH}-\mathrm{T}-2$ and 3 '-OH-HT-2 toxins.

\section{References}

1) Ueno, Y., Hosoya, M., Morita, Y., Ueno, I., Tatsuno, T.: J. Biochem., 64, 479 (1968).

2) Ueno, Y., Nakajima, M., Sakai, K., Ishii, K., Sato, N., Shimada, N.: J. Biochem., 74, 285 (1973).

3) Chu, F. S., Grossmam, S., Wei, Ru-Dong, Mirocha, C. J.: Appl. Environ. Microbiol., 37, 104 (1979).

4) Hunter, JR., K. W., Brimfield, A. A., Miller, M., Finkelman, F. D., Chu, S. F.: Appl. Environ. Microbiol., 49, 168 (1985). 